\title{
NOT LETTING THEM WHISTLE: THE LABOUR APPEAL COURT'S APPROACH TO THE PROTECTED DISCLOSURES ACT AND PROTECTING PARLIAMENT'S EMPLOYEES
}

\author{
Craig Bosch
}

$B A \quad L L B \quad L L M$

Arbitrator and Mediator

Research Associate of the Faculty of Law

Nelson Mandela Metropolitan University

Port Elizabeth

Rochelle le Roux

BJuris LLB LLM PGDip LLM PhD

Professor of Law, University of Cape Town

\section{SUMMARY}

The Protected Disclosures Act 26 of 2000 was passed with the aim of protecting whistleblowers in the workplace. The decision of the Labour Appeal Court in Parliament of the Republic of South Africa v Charlton (2010 31 ILJ 2353) highlights the potential shortcomings of the Act which, if interpreted in the manner suggested by this court, could deprive many whistleblowing employees of the protection that they deserve. This article suggests that the Labour Appeal Court failed to have proper regard to the objectives of the Protected Disclosures Act, the essential principles contained in the Constitution and, more particularly the Bill of Rights as well as international law. If it had, it would have been compelled to conclude that the Protected Disclosures Act can and should be interpreted as applying to disclosures concerning the misconduct of Members of Parliament by the employees of Parliament.

\section{1}

\section{INTRODUCTION}

"Whistleblowers" are people who disclose information relating to criminal, unlawful or irregular conduct. In the employment context employees who are whistleblowers need protection from reprisals by employers if whistleblowing is to be encouraged. It ought to be encouraged given that it prevents wrong- 
doing and harm to others. It promotes good governance via transparency and openness which in turn ensure accountability. ${ }^{1}$ In the public sector whistleblowers are a means to monitor the allocation of public resources, to prevent corruption, "the waste of public funds or other abuses of stateconferred privileges or authority" ${ }^{\prime 3}$ and generally monitor the performance of officials vested with the public's trust. Whistleblowing emanates from those best placed to detect irregular activity early and extends the reach of institutions tasked with monitoring and investigating such activity. In so doing it also acts as a deterrent to those contemplating criminal or unlawful activity. ${ }^{4}$

It is for reasons like these that the South African government sought to protect whistleblowers in the employment context via the introduction of the Protected Disclosures Act ${ }^{5}$ (PDA). That statute recognises that

"criminal and other irregular conduct in organs of state and private bodies are detrimental to good, effective, accountable and transparent governance in organs of state and open and good corporate governance in private bodies and can endanger the economic stability of the Republic and have the potential to cause social damage".

It seeks to

"create a culture which will facilitate the disclosure of information by employees relating to criminal and other irregular conduct in the workplace in a responsible manner by providing comprehensive statutory guidelines for the disclosure of such information and protection against any reprisals as a result of such disclosures; promote the eradication of criminal and other irregular conduct in organs of state and private bodies".

This article will focus on the Labour Appeal Court's decision in Parliament of the Republic of South Africa $v$ Charlton. ${ }^{8}$ It is an important decision in that it highlights a significant potential gap in the PDA. We are of the view that the manner in which the court assessed the relevant statutory provisions and its conclusion regarding them are cause for concern. This article will explain the nature of that concern and consider whether the court could have come to another conclusion based on the wording of provisions as they stand, whether those provisions need to be amended and what other remedies might be available to employees in Mr Charlton's position.

At the time we began writing this article, the decision of the Labour Appeal Court was on appeal to the Supreme Court of Appeal. That court sub-

\footnotetext{
Martin The Status of Whistleblowing in South Africa: Taking Stock (2010) 27. See also Tshishonga v Minister of Justice and Constitutional Development 200728 ILJ 195 (LC) 216 and 225.

2 Camerer "Protecting Whistleblowers in South Africa: The Protected Disclosures Act, No 26 of 2000" Institute of Security Studies, Occasional Paper 472001 http://www.issafrica.org/ Pubs/Papers/47/Paper47.html.

3 Merk $v$ International Association of Bridge, Structural, Ornamental and Reinforcing Iron Workers, Local 771, [2005] 3 S.C.R. 425 par 14.

$\mathrm{Ibid}$; and the authorities referred to there.

26 of 2000.

Preamble of the Protected Disclosures Act 6 of 2000

Ibid.

201031 ILJ 2353 (LAC).
} 
sequently rendered its decision and upheld the appeal. ${ }^{9}$ However, the appeal was upheld on a very narrow, technical basis relating to whether the Labour Court's decisions on certain exceptions were appealable. That is not an issue that we have concerned ourselves with in this article, instead we have focused on the reasons the Labour Appeal Court gave for its decision. Those are of far greater general significance than the technical issues relating to the appealability of decisions on exceptions.

\section{BACKGROUND}

The facts of the case are fairly straightforward. Mr Charlton was employed by Parliament as its chief financial officer. He made allegations relating to members of Parliament (and a member of the Parliamentary service) being involved in fraud relating to travel benefits. Charlton was called to a disciplinary hearing and subsequently dismissed. He referred a dispute to the Labour Court claiming that his dismissal was contrary to section $187(1)(\mathrm{h})$ of the Labour Relations Act $^{10}$ (LRA) and thus automatically unfair because the reason for the dismissal was

"a contravention of the Protected Disclosures Act, 2000, by the employer, on account of an employee having made a protected disclosure defined in that Act".

It appears from a reading of the Labour Court's judgment that Charlton also alleged that his dismissal was automatically unfair because it was contrary to section 5 of the LRA. ${ }^{11}$ That issue did not feature in the LAC's decision, but it is something to which we shall return below. Charlton also alleged that his dismissal was contrary to section 188 of the LRA in that there was no fair reason for it and the employer had not followed a fair procedure prior to dismissing him.

When the matter came before the Labour Court the employer raised a number of exceptions to Charlton's claims. Two of them formed the subject matter of the judgments, that is, that Charlton's claims did not disclose a cause of action because members of Parliament are not employees or employers for the purposes of the PDA and, secondly, that the Labour Court had no jurisdiction to determine whether Charlton's dismissal was unfair as far as section 188 was concerned. That was an issue that had to be decided in arbitration. ${ }^{12}$

This article will focus on the first of the exceptions mentioned above. It is worth explaining in more detail why it was significant to decide whether members of Parliament were employers or employees for the purposes of the PDA.

9 Charlton v Parliament of the Republic of South Africa (680/2010) [2011] ZASCA 132 (16 September 2011).

1066 of 1995.

11 S 187(1) provides that a "dismissal is automatically unfair if the employer, in dismissing the employee, acts contrary to section 5".

12 We would note that it is remarkable that Parliament was resistant to dealing with the merits of Charlton's claim given its status as an embodiment of democracy (in which transparency and accountability play a vital role) and an important repository of the values contained in the Constitution. 
As far as the PDA is concerned:

“(i) 'disclosure' means any disclosure of information regarding any conduct of an employer, or an employee of that employer, made by any employee who has reason to believe that the information concerned shows or tends to show one or more of the following:

(a) That a criminal offence has been committed, is being committed or is likely to be committed;

(b) that a person has failed, is failing or is likely to fail to comply with any legal obligation to which that person is subject;

(c) that a miscarriage of justice has occurred, is occurring or is likely to occur;

(d) that the health or safety of an individual has been, is being or is likely to be endangered;

(e) that the environment has been, is being or is likely to be damaged;

(f) unfair discrimination as contemplated in the Promotion of Equality and Prevention of Unfair Discrimination Act, 2000 (Act No. 4 of 2000); or

(g) that any matter referred to in paragraphs (a) to (f) has been, is being or is likely to be deliberately concealed" (authors' own emphasis added).

\section{THE DECISION OF THE LAC: A CRITICAL ASSESSMENT}

The LAC's decision in relation to the first exception turned on whether Charlton's claims related to the conduct of an employer ${ }^{13}$ or an employee. ${ }^{14}$ The decision was, with respect, haphazard and the reasoning unconvincing. The court began its analysis by stating that it was required to determine "whether the PDA is applicable to MPs" " With respect, that was not entirely correct. What the court had to determine was whether Charlton's claims related to a "disclosure" for the purposes of the PDA. Part of that enquiry related to the issue of whether MPs are employers or employees for the purposes of the definition of "disclosure". The court was thus not required to decide whether the PDA ought to apply to MPs. This misplaced emphasis is an important feature of the judgment in that it influenced the court's thinking in several important respects.

13 The PDA provides a definition of "employer", ie,

"any person-

(a) who employs or provides work for any other person and who remunerates or expressly or tacitly undertakes to remunerate that other person; or

(b) who permits any other person in any manner to assist in the carrying on or conducting of his, her or its business, including any person acting on behalf of or on the authority of such employer."

14 The definition of "employee" is the same as that contained in the LRA, ie,

"(a) any person, excluding an independent contractor, who works for another person or for the State and who receives, or is entitled to receive, any remuneration; and

(b) any other person who in any manner assists in carrying on or conducting the 5 Par 16. business of an employer." 


\section{(a) The presumption that the legislature did not intend to bind the state}

Having concluded that the case hinged on statutory interpretation, the court embarked on a discussion of the presumption that the state is not bound by statutes. The court made no finding on the whether that presumption still has any place in a constitutional dispensation despite raising the issue or what effect the presumption (if the court was applying it) had on the court's interpretation of the PDA, and despite referring to it, failed to address the criticism and extremely valid conclusion of Devenish that:

"it is manifestly clear that all organs of State in the new constitutional dispensation should indeed be bound by legislation, unless it can be manifestly demonstrated that in particular circumstances, the State organ concerned, would be hampered in the execution of its duties and functions, if it were indeed bound. This is, it is submitted, something that would have to be proved, and cannot merely be presumed. Both the letter and spirit of the Constitution will not tolerate the lawlessness of State organs. This means that the unqualified presumption that the State is not bound by legislation in its traditional form is no longer valid and is incompatible with nature and operation of the presumptions in general as they now apply in of the Constitution and the common law as developed in terms of section 32(2) of the Constitution. Its application in the present jurisprudential and constitutional dispensation would be anachronistic".

Instead, the court stated that:

"This presumption will have to be developed in line with the new constitutional order, which is premised on governmental accountability and transparency. To hold that the provisions of the PDA bind MPs would hamper the execution of their duties and functions. In any event Parliament has its own mechanism to deal with MPs whose conduct fails to pass muster."

Although the court appeared to accept that the presumption must be developed or, one might suggest, eradicated ${ }^{17}$ it, without even attempting to advance reasons why they "would be hampered in the execution of [their] duties and functions, if [they] were indeed bound", ${ }^{18}$ concluded that MPs would somehow be obstructed in the performance of their duties if employees could make disclosures relating to their misconduct. That is a startling conclusion and certainly one which the court ought to have explained. It beggars belief that MPs, who can surely be expected to conduct themselves in an honest, ethical and lawful way, could be said to be hindered in their roles if their dishonest, unethical and unlawful conduct could be disclosed. It is not clear what additional obligations the PDA would place on MPs that would impede them and it suggested that there are none.

The court did not elaborate on the "mechanisms" Parliament would utilize to deal with MPs who misconduct themselves so one is left to speculate what those might be. There is a Code of Conduct for Office-Bearers and Members which deals with "disclosure of financial interests and provisions

16 Devenish "The State is Not Presumed to be Bound by Statute - A Constitutional and Jurisprudential Anachronism" 2009 Obiter 1727.

17 See the discussion in de Ville Constitutional \& Statutory Interpretation (2000) 64 et seq.

18 Devenish 2009 Obiter 27. 
pertaining to the disclosure of conflicts of interests". It is a guide to MPs around what they ought to disclose and says nothing about the general conduct expected of MPs. In addition, the penalties that might be taken against MPs who fail to comply with the code are lightweight. It is clearly not sufficient to leave Parliament to deal with misbehaving MPs. Apart from the need for transparency and accountability to the electorate, certain conduct such as crimes cannot be dealt with by Parliament's internal mechanisms and must be disclosed to the appropriate authorities. And it is strange that the LAC felt that Parliament's mechanisms would be sufficient in all cases.

Most importantly, the code governing the conduct of MPs provides absolutely no protection to those who make the relevant disclosures and leaves them vulnerable to victimization as a reward for revealing impropriety. In addition, we would suggest that MPs, more than most, should be held to account for improper conduct and such conduct should be exposed by any and all means possible. There would appear to be no reason why it is desirable to leave it to Parliament's internal mechanisms to investigate and deal with MPs misconduct.

It is also questionable why, if the court was going to seek assistance from the presumption that the state is not bound by the statute, it did not consider whether the presumption had been rebutted. Instead, the court perfunctorily referred to two factors, apparently to reinforce the presumption, and left it at that. The considerations to be contemplated when dealing with the presumption were set out in Administrator Cape $v$ Raats Rontgen and Vermeulen $^{19}$ (to which the LAC did not refer) as follows:

"1. The State is not bound by its own enactments, except by express words or by necessary implication, ie if an intention to be bound appears clearly from the nature of the enactment.

2. For the purpose of deciding whether a statute falls within the narrow scope of the exception, the Court may look not only upon the language of the enactment, but also at the surrounding circumstances and may consider its objects, its mischiefs and its consequences.

In other words, the purpose of the statute, the circumstances pertaining at the time when it was passed and the consequences if the State were exempted or bound, are all factors that must be taken into account. Considerations of public policy are therefore also relevant.

3. However, the mere fact that a statute was passed for the public benefit is not in itself a sufficient consideration from which an inference that the State was intended to be bound may be justified. It must be shown that if the State were not bound, the purpose sought to be achieved by the enactment would be frustrated ...

4. In the inferential process to determine the intention of the Legislature other common law presumptions employable as indicators of such intention are

A cursory glance at these principles indicates that the presumption may well not have operated to favour an interpretation of the PDA that excluded disclosures regarding the conduct of MPs. The statute is obviously one passed for the public benefit for the reasons that have been set out above. The purposes of the enactment, that is, "good, effective, accountable and

\footnotetext{
19921 SA 245 (A).

20262.
} 
transparent governance" and promoting "the eradication of criminal and other irregular conduct in organs of state" would be frustrated if the PDA does not apply to disclosures relating to the conduct of MPs. And the language of the PDA makes it clear that the PDA is directed at protecting whistleblowers who are state employees from being subjected to occupational detriments by the state. The PDA is aimed at effective and accountable governance in organs of state which are defined "as any department of state or administration in the national or provincial sphere of government or any municipality in the local sphere of government". Section 7 of the PDA deals with disclosures to a member of Cabinet or the Executive Council of a province where the employer is, inter alia, an organ of state. This demonstrates a clear intention that the state should be bound and improprieties by its actors checked by the protections offered by the PDA.

There are also numerous considerations of public policy (which is now embodied in the Constitution ${ }^{21}$ ) indicating that the PDA should apply to disclosures such as Charlton's. The founding values of the Constitution include a desire to "ensure accountability [on the part of the state], responsiveness and openness". ${ }^{22}$ Protecting employees of parliament would further that objective. In addition, a number of the fundamental rights in the Bill of Rights would be protected or promoted if the PDA protected parliament's employees. Those would include dignity, freedom of expression and (if a disclosure related to the misallocation of funds destined for housing, health care or education) the rights to housing, health care and education. ${ }^{23}$ Section 32(1)(b) guarantees the right of access to information that is held by another person that is required for the exercise or protection of any rights. If any of the aforementioned fundamental rights is threatened any member of the public has a right to the information held by the parliamentary whistleblower. Section 41 of the Constitution provides that all spheres of government (which would include parliament) must "provide effective, transparent, accountable and coherent government ..." Section 57 and 70 permit the National Assembly and the National Council of Provinces to make rules and orders concerning their business. However, in doing so due regard must be had, inter alia, to accountability and transparency.

\section{(b) Are MPs employees for the purposes of the PDA?}

The strange reasoning the court applied when dealing with the presumption was compounded when it turned to deal with the question of whether MPs are "employees".

${ }^{21}$ See Barkhuizen v Napier 20075 SA 323 (CC) 333 et seq and the authorities referred to there. The court stated that "[p]ublic policy represents the legal convictions of the community; it represents those values that are held most dear by the society. Determining the content of public policy was once fraught with difficulties. That is no longer the case. Since the advent of our constitutional democracy, public policy is now deeply rooted in our Constitution and the values that underlie it".

22 S 1 (d).

23 Ss $10,16,26,27$ and 29 respectively. 
The PDA defines an "employee" as:

"(a) any person, excluding an independent contractor, who works for another person or for the State and who receives, or is entitled to receive, any remuneration; and

(b) any other person who in any manner assists in carrying on or conducting the business of an employer."

This is the same definition of "employee" contained in the LRA and other labour legislation. In its discussion of whether MPs are employees the LAC stated that:

"To subject MPs to the PDA may, in practice, run the risk of frustrating the democratic process. An extension of the application of 'employee' under the PDA to include MPs might cause statutes to become more complex. MPs ought to be entirely independent."

This is puzzling, both for the contents of the statements and the lack of any substantiation for them. It is, exceedingly difficult to understand why applying the PDA to disclosures relating to the conduct of MPs would frustrate the democratic process. On the contrary, there is every indication that that would further the democratic endeavour. Similarly, the court's next statement is incomprehensible. The connection between allowing MPs' conduct to be subject to scrutiny via disclosures around it and the complexity of legislation is entirely unclear. So is the link between the independence of MPs and allowing their dirty laundry to be aired via the PDA. If the court was going to make these startling findings it was incumbent on it to provide clear reasons for those findings. We would suggest that those reasons would be difficult to locate.

What was more compelling was the finding that MPs are office-holders and not employees. ${ }^{24}$ They are elected to office and remunerated in accordance with the Remuneration of Public Office Bearers Act. ${ }^{25}$ They are answerable to the Republic and the Constitution. In addition, MPs could not be regarded as employees because they could not have recourse to the Labour Court if they lost their seat after an election. This last point does not take the argument much further given that it seems to relate more to whether people who are employees could prove that they were "dismissed" within the meaning of the LRA. However, regarding MPs the other reasons supplied by the court make it clear that MPs do not resemble employees in the conventional sense. They do not have an employer with whom they are in a work relationship or to whom they are subordinate. The usual hallmarks ${ }^{26}$ of an employment relationship are, admittedly, missing.

24 The LAC held that MPs are excluded from the provisions of the LRA and should thus also be taken to be excluded from the PDA. However, it is not clear why the court was so certain that MPs cannot be viewed as "employees" for the purposes of the LRA. The court referred to no authority for that proposition nor are MPs amongst the categories of workers who are expressly excluded from the LRA in $\mathrm{s} 2$.

2520 of 1998.

26 See, eg, State Information Technology Agency (Pty) Ltd v Commission for Conciliation, Mediation \& Arbitration 200829 ILJ 2234 (LAC); and Pam Golding Properties (Pty) Ltd v Erasmus 201031 ILJ 1460 (LC). 
Assuming that MPs could not be regarded as employees for the purposes of the LRA, the question arises whether a court could not interpret the definition of "employee" differently in the PDA to the manner in which it might be interpreted in other legislation. That is, MPs could be taken to be employees for the purposes of the PDA but not the LRA given the context and objects of each piece of legislation. In Charlton the LAC held that the PDA and the LRA are part of a single statutory scheme and that the word "employee" should thus be given the same meaning in both of them. In other words, because the definition of "employee" is the same in both acts and because of the legislature's choice to regard dismissals for making a protected disclosure as an automatically unfair dismissal, "employee" should be taken to mean the same thing under both acts. While, on the face of it, this may seem like a valid approach, it disregards the different legislative origins of the LRA and the PDA. ${ }^{27}$

The PDA has its roots in the Open Democracy Bill of 1998. The Bill aimed to give effect to one of the values embedded in the preamble of the Constitution, namely a democratic and open society, by introducing means to address the secretive and unresponsive public and corporate culture that prevailed in pre-1994 South Africa and by creating a framework within which a culture of transparency, responsibility, accountability, openness and disclosure could be promoted. In order to achieve this, the Bill regarded access to information and whistleblowing "as compl[e]mentary and interdependent essential practices". However, the Bill was never enacted, but its two main pillars subsequently became the Promotion of Access to Information $\mathrm{Act}^{28}$ and the PDA. ${ }^{29}$

The PDA is based on the Public Interest Disclosures Act of 1998 (PIDA) in the United Kingdom which also facilitates whistleblowing protection via employment legislation (the Employment Rights Act of 1996). However, for purposes of this case note, it is important to note two differences between the PDA and PIDA. First, protection in PIDA is extended (via s 43K) to those workers who are not in traditional employment relationships. Second, unlike the PDA, compensation for unfair dismissal for making a protected disclosure is not limited and provision is made for the payment of damages. ${ }^{30}$

Whistleblowing legislation is also closely associated with international conventions aimed at addressing corruption generally. ${ }^{31}$ We shall return to these below, but suffice to say for now that, while many countries have given effect to their duties under these conventions by enacting legislation protecting whistleblowers in the workplace, such legislation should not for this reason be seen as implanted in employment legislation. Such legislation

27 See Du Plessis Re-Interpretation of Statutes (2002) 114 for the need to consider the broader historical context when interpreting legislation.

2 of 2000 .

29 Martin 38-40.

S 124(1A). See also Martin "Ten Years of Whistle Blowing Protection in South Africa: A Review of the Past and Lessons for the Future" http://www.opendemocracy.org.za/ images/docs/Imartinpaper.pdf accessed 2010-10-01.

31 United Nations Convention against Corruption, 2003 and African Union Convention on Preventing and Combating Corruption, 2003; both ratified by South Africa. 
is simply part of a broader strategy to address corruption. The judgment in Charlton totally disregarded this genesis of the PDA.

Regardless of the historical context, Parliament may, when passing legislation, express a clear intention to locate that legislation within a particular framework. Once this intention is clear, it must be given effect to. This was the approach adopted by the LAC in Charlton. However, may it be said, when comparing the PDA and the LRA, that it is clear that Parliament actually intended to create a single statutory scheme? All that Parliament did by enacting the PDA was to create some interface with the LRA and not to place it squarely within the framework of labour-relations legislation. In other words, not "every issue arising under the PDA is a "quintessential labourrelated issue", 32

Section 4 of the PDA is the clearest evidence of this mindset. This section provides that an employee who has been subjected to an occupational detriment may approach any court having jurisdiction, including the Labour Court, for appropriate relief, or to pursue any other process allowed or prescribed by any law. This section further provides that when the occupational detriment manifests in the form of a dismissal or in any of the other defined conduct short of dismissal, and the employee chooses to approach the Labour Court, such a dismissal or conduct must be processed as either an automatically unfair dismissal or an unfair labour practice under the LRA. It has repeatedly been held that this section does not oblige the employee to refer the matter to the Labour Court. ${ }^{33}$ It simply means, in the event of it being approached, the Labour Court has jurisdiction to deal with it as either an automatically unfair dismissal or unfair labour practice in accordance of the processes and remedies provided for in the LRA. This is completely contrary to the general structure of the LRA which endeavours, first to channel all disputes via the CCMA and the Labour Court system created by the LRA and, second confers exclusive jurisdiction on the LRA in respect of most labour-related disputes. ${ }^{34}$ Significantly, the two statutes are also administered by two different state departments.

The approach adopted by the LAC in Charlton appears to be a manifestation of what Simon Deakin refers to as the unitary concept of the contract of employment which disregards the differences between the various forms of wage-dependent labour and treats all wage-dependent labour the same. ${ }^{35}$ In this case, it (the unitary concept) manifests in a tendency to interpret the meaning of "employee" as used in different legislation in the same manner regardless of the context and the origin of the specific legislation. However, in the same way that the unitary concept of the contract of employment cannot accommodate the diverse patterns of modern employment and thus ensure protection for all employees, the unitary approach to the interpretation of the meaning of "employee" has the potential of undermining the purpose of the legislation which is being

32 City of Tshwane Metropolitan Municipality v Engineering Council of South Africa 201031 ILJ 322 (SCA) 342.

33 Ibid. See also Young v Coega Development Corporation (Pty) Ltd (1) 20096 BLLR 597 (ECP); and Jordan v MEC for Finance, Eastern Cape [2007] JOL 19802 (Ck).

34 S 157(1) of the LRA.

35 Freedland The Personal Employment Contract (2006) 15-17. 
interpreted and of depriving the employee from the protection he or she is supposed to get via that legislation. This is exactly what has happened in this matter.

The PDA does not have its genesis in employment relations. Its genesis is the desire to create an open society and interpreting "employee" in the PDA in the same way that it would be interpreted in the context of "proper" labour relations legislation, negates both the origins and objects of the PDA. In other words, while the LRA aims to regulate the labour market and employment; the PDA aims to advance an open society. The fact that the PDA chose the workplace as the location to do this, is incidental and therefore it must be questioned whether, as was held by the LAC, the exclusion of MPs from the LRA "logically" extends to the PDA. ${ }^{36}$ If MPs are indeed not employees for the purpose of the PDA, the reason(s) for their exclusion must be found elsewhere, not in a supposed statutory scheme.

In finding that MPs could be regarded as employees for the purposes of the PDA the Labour Court in Charlton found that MPs were the employees of Parliament which is an organ of state. However, neither the Labour Court nor the LAC referred to section 47 of the Constitution which provides as follows:

"47. Membership (1) Every citizen who is qualified to vote for the National Assembly is eligible to be a member of the Assembly, except -

(a) anyone who is appointed by, or is in the service of, the state and receives remuneration for that appointment or service ..."

That provision prohibits members of the National Assembly from being employees of the state in any of its manifestations.

We would suggest that on balance the better view is probably that MPs are not "employees", but not for the reasons advanced by the LAC. That is because of section 47 of the Constitution and the unique nature of the context in which MPs work, are remunerated and held accountable. ${ }^{38}$ However, we will argue below that MPs should be regarded as "employers" for the purposes of the PDA.

\section{(c) Are MPs employers for the purposes of the PDA?}

The PDA defines "employer" as any person

"(a) who employs or provides work for any other person and who remunerates or expressly or tacitly undertakes to remunerate that other person; or

(b) who permits any other person in any manner to assist in the carrying on or conducting of his, her or its business, including any person acting on behalf of or on the authority of such employer."

Par 31

37 See KwaZulu-Natal Provincial Treasury v General Public Service Bargaining Council 2006 27 ILJ 163 (LC).

38 See Le Roux The World of Work: Forms of Engagement in South Africa, Monograph 02/2009, Institute of Development and Labour Law, University of Cape Town 50-52. 
The LAC dismissed the argument that MPs are employers for the purposes of the PDA in the following, brief, terms:

"The definition of 'protected disclosure' in the PDA specifically mentions certain categories of persons to whom the PDA applies. One specific category is a member of Cabinet or the Executive Council. If Parliament had intended to include MPs within the ambit of this definition then it would have clearly done so.

Parliament submitted that parliamentary staff are answerable to the Secretary of Parliament and not to MPs. This point is important. Parliamentarians must be allowed to focus on their constitutional duty to make law. A MPs (sic) portfolio ought not to be cluttered with the additional and onerous responsibilities of being an 'employer' of parliamentary staff. This would hinder the effective performance of their duties and functions. This court accordingly finds that MPs are not included in the PDA.",39

Significantly, the definition of "protected disclosure" in the PDA gives no indication to whom the PDA applies. Rather, it sets out in broad terms when a disclosure will be protected. In order to be protected disclosures must, inter alia, be made to specified persons. The PDA then determines the requirements for protection which differ according to whom the disclosure is made. Thus, the specific and different requirements for protection of disclosures made to employers, legal advisors, the Public Protector, members of the cabinet and the executive council, etcetera. It most certainly does not indicate that the PDA does or does not apply to cabinet ministers and members of the executive council or anyone else for that matter.

There is a definition of "employer" in the PDA to which (somewhat remarkably) the LAC made no reference in determining whether MPs could regarded as employers. We would suggest that that definition is determinative of the question whether MPs can be regarded as employers and thus whether disclosures relating to their conduct would qualify as "disclosures" for the purposes of the PDA. We shall advance arguments relating to how the definition of employer in the PDA should be interpreted. However, it is worth observing that the court's remarks relating to cluttering and hindering MPs in their duties are, as with its observations regarding whether MPs are "employees", speculative and are unsupported by cogent reasoning and evidence. Furthermore, we also suggest, for the same reasons advanced earlier, that the understanding of employer in the PDA should be divorced from its understanding in terms of employment legislation.

Part (b) of the PDA's definition of "employer" is slightly ambiguous. It could be read as saying that an employer is someone who permits others to assist in the carrying on or conducting of its business and also permits people to act on its behalf or on its authority. Alternatively, it could be read as meaning that those who act on behalf of or on the authority of the employer are themselves to be regarded as employers. The latter interpretation (as was submitted by counsel for Charlton) is to be preferred. Logically, people would to all intents and purposes be acting as (or would effectively be) the employers when acting on their behalf or with their authority. Counsel for Parliament argued in the LAC that Parliament has a legal personality distinct

39 Par 32-33. 
from its constituent MPs and that MPs can thus not be employers. However, Parliament cannot act on its own. It is for MPs to undertake a variety of tasks which facilitate the effective functioning of Parliament. They therefore act on its behalf in order to keep it operational.

There is a number of reasons why a broader interpretation of the definition of employer should be preferred. We shall examine each of those in more detail below.

\title{
(i) Giving effect to the objects of the PDA, transparency and accountability
}

The PDA gives courts significant guidance as to how it should be interpreted, yet the LAC (despite the submissions by counsel for the respondent) made no mention of the effect of the objects of the PDA and the Constitution on how the provisions of the PDA should be given meaning. That was a fatal omission. The preamble of the PDA makes the purposes of the Act very clear: eradicating criminal and other improper conduct in the private and public sectors, ensuring good, effective, accountable and transparent governance, creating a culture of whistleblowing and properly protecting whistleblowers. Those are amplified in section 2 which contains the objects of the PDA which include protecting employees in the private and public sectors from suffering occupational detriments for making protected disclosures.

In City of Tshwane Metropolitan Municipality $v$ Engineering Council of South Africa ${ }^{40}$ the Supreme Court of Appeal made it clear that courts should interpret the PDA in a manner that is consistent with its stated purposes. Albeit in a different context, the following passage from the judgment is instructive:

\begin{abstract}
"A further difficulty with this approach to the nature of information under the PDA is that its narrow and parsimonious construction of the word is inconsistent with the broad purposes of the Act, which seeks to encourage whistleblowers in the interests of accountable and transparent governance in both the public and the private sector. That engages an important constitutional value and it is by now well-established in our jurisprudence that such values must be given full weight in interpreting legislation. A narrow construction is inconsistent with that approach. On the construction contended for by Mr Pauw the threat of disciplinary action can be held as a sword of Damocles over the heads of employees to prevent them from expressing honestly held opinions to those entitled to know of those opinions. A culture of silence rather than one of openness would prevail. The purpose of the PDA is precisely the opposite."
\end{abstract}

Section 195 of the Constitution provides that a high standard of professional ethics, the efficient, economic and effective use of resources, impartiality and fairness, accountability and transparency are basic values in

\footnotetext{
Supra.

41 343-344; and see also the significance attached the preamble of the PDA in Young $v$ Coega Development Corporation (Pty) Ltd (2) 200930 ILJ 1786 (ECP) 1796.
} 
public administration. Those are the values which, as the SCA indicated, "must be given full weight in interpreting legislation".

The PDA and section 1, 41, 57, 70 and 195 make it plain that the values of transparency and accountability are fundamentally important. They ought to have been taken into account in adopting a broader interpretation of the PDA which would have the effect of extending its reach to include disclosures relating to the activities of MPs by regarding them as "employers" as defined in the PDA.

\section{(ii) Section 39(2) and the fundamental rights in the Constitution}

Apart from the provisions of the PDA and the above-mentioned provisions of the Constitution, there is further impetus for a more inclusive interpretation of the definition of employer in the PDA. That is contained in section 39(2) of the Constitution which requires the courts to "promote the spirit, purport and objects of the Bill of Rights" when interpreting legislation. That raises the question which rights in the Bill of Rights are implicated when it comes to interpreting the PDA.

\section{The right to fair labour practices}

Counsel for Charlton appears to have argued that the right to fair labour practices requires that employees are not prejudiced for making disclosures relating to improprieties committed in the workplace. That kind of unfair labour practice could have been avoided by giving the PDA a broader reach. It is debatable whether employees' being subjected to a detriment for making disclosures falls within the reach of the right to fair labour practices. The legislature does not obviously envisage that if regard is had to the preamble of the PDA which makes specific mention of "human dignity, equality and freedom".

However, the preamble of the PDA does not determine the scope of the constitutional right. The Constitution simply and very broadly guarantees to everyone a right to fair labour practice, a concept that the Constitutional Court found "incapable of precise definition". ${ }^{43}$ However, the LRA is one attempt to embody the general guarantee and is to that extent a codification of the right to fair labour practices. If regard is had to the LRA as a means to determine the content of right to fair labour practices the right clearly encompasses protection against occupational detriments for making protected disclosures. ${ }^{44}$ That conclusion is reinforced if regard is had to section 39(1)(a) which provides that, when interpreting the Bill of Rights, a court "must promote the values that underlie an open and democratic society". Included amongst those would be transparency and accountability. Those values would be further entrenched if employees making protected disclosures were protected by the right to fair labour practices. Finally,

42 The Constitutional Court adopted a similar approach to interpreting legislation in African Christian Democratic Party v Electoral Commission 20063 SA 305 (CC) par 27-28.

43 NEHAWU v University of Cape Town 200324 ILJ 95 (CC) 110.

44 See $s$ 186(2)(d) and s 187(1)(h). 
international law supports a conclusion that the right to fair labour practices includes such protection. ${ }^{45}$

In summary then, if protection against employer retribution for protected disclosures falls within the right to fair labour practices the case the LAC ought to have adopted a broader interpretation of the PDA.

\section{The right to freedom of expression}

The right to freedom of expression is of obvious significance given that it is entrenched in the Bill of Rights. ${ }^{46}$ In explaining why that right is of such importance the Constitutional Court has noted that

"Freedom of expression is an important instrument to a democratic government. It is especially important to our constitutional democracy, which is both representative and participatory. As the Preamble of the Constitution makes plain, ours is 'a democratic and open society in which government is based on the will of the people'. Free expression of opinion, including critical opinion, is essential to the proper functioning of our constitutional democracy. As this Court pointed out in Khumalo and Others $v$ Holomisa, freedom of expression is 'integral to a democratic society', and without it, 'the ability of citizens to make responsible political decisions and to participate effectively in public life would be stifled"' (footnotes omitted).

It is particularly significant for the purposes of this paper that the wording of section 16 of the Constitution (which contains the right to freedom of expression) specifically includes a right to "receive or impart information or ideas". That would give the whistleblower the right to disclose information regarding improprieties by MPs and the public governed by those MPs the right to receive it. Of course, the right to freedom of expression must be exercised within legitimate limits. ${ }^{48}$

Canadian courts have long recognized that the right to freedom of expression permits employees (particularly those in the public service) to impart information regarding improprieties committed by their employers. Employees may convey information that is detrimental to their employer despite their being bound by a duty of loyalty. However, the freedom of expression is not unbounded and the courts have sought to strike an appropriate balance between the interests of employees and employers. ${ }^{49}$ Thus, it has been suggested that the employee's freedom of expression

45 S 39(1)(b) stipulates that when interpreting the Bill of Rights courts must consider international law. See the discussion on the contents of applicable international instruments below.

46 S 16.

47 Per Ngcobo CJ in The Citizen 1978 (Pty) Ltd v McBride (CCT 23/10) 2011 ZACC 11 par 141. See also South African National Defence Union v Minister of Defence 19994 SA 469 (CC) 477; S v Mamabolo (E TV and Others Intervening) 20013 SA 409 (CC) 428-429; and Khumalo $v$ Holomisa 20025 SA 401 (CC) 416 et seq.

$48 \quad S$ v Mamabolo (E TV and Others Intervening) supra 430 and 433 et seq; and O'Regan $\mathrm{J}$ in NM v Smith 20075 SA 250 (CC) 287-288.

49 Fraser $v$ Public Service Staff Relations Board 1985 CanLii 14 SCC; Alberta Union of Provincial Employees v Alberta 2002 ABCA 202 (CanLii); Haydon v Canada (Treasury Board) [2004] FC 749; and Read v Canada (Attorney General) 2006 FCA 283 (CanLii). The European Court of Human Rights had occasion to deal with this issue in Guja v Moldova, Application no. 14277/04, 12 February 2008. See in particular par 69-78. 
might be limited by the duty of loyalty (and the employee found guilty of misconduct for disclosing the information) when, for example, the information is inaccurate, untruthful or confidential. Regard might also be had to the manner in which the information was made public, the extent to which the employer's ability to conduct its business was compromised, the public interest in the information, etcetera. ${ }^{50}$ It has been held that

"[t]he exceptions to the duty of loyalty are in place in order to embrace matters of public concern and to ensure that the duty of loyalty impairs the freedom of expression as little as reasonably possible in order to achieve the objective of an impartial and effective public service".

It seems obvious that South African courts must also accept that the PDA gives effect to the right to freedom of expression. It also seeks to facilitate the balance between employer and employee interests referred to in the Canadian context and to determine the parameters of the kind of acceptable limitations on the freedom of expression envisaged by our Constitutional Court. Those considerations should have prompted the LAC to interpret the PDA as applying to disclosures relating to improprieties by MPs. That would allow for the protection of the right of freedom of expression of whistleblowers like Charlton if his disclosure fell within the parameters determined by the PDA.

\section{The right of access to information}

The purpose behind the right of access to information is "to promote open and accountable government" ${ }^{, 52}$ and in Brümmer $v$ Minister for Social Development ${ }^{53}$ the Constitutional Court stated that

"[t]he importance of this right ... in a country which is founded on values of accountability, responsiveness and openness, cannot be gainsaid. To give effect to these founding values, the public must have access to information held by the State. Indeed one of the basic values and principles governing public administration is transparency. And the Constitution demands that transparency 'must be fostered by providing the public with timely, accessible and accurate information'".

The right of access to information might be relied on in interpreting the PDA in two ways. Firstly, everyone has the right to information held by the state. Information known to those working in or for Parliament might be regarded as such information. In addition, section 32 of the Constitution guarantees a right of access to information including the right to "any information that is held by another person and that is required for the exercise and protection of any rights". That works in concert with the right to

50 Brown and Beatty Canadian Labour Arbitration 3ed 7-117 as quoted in Haydon v Canada (Treasury Board) supra par 44

51 Haydon v Canada (Treasury Board) supra par 45.

52 Davis in South African Constitutional Law: The Bill of Rights (last updated September 2011) 26-7. The preamble to the Promotion of Access to Information Act 2 of 2000 states that one of the objectives of the Act (and thus one of the components of the right of access to information) is to "foster a culture of transparency and accountability in public and private bodies".

5320096 SA 323 (CC).

$54 \quad 345-346$ 
freedom of expression to entitle the public affected by the misconduct of MPs to information relating to such. The "rights" referred to in section 32 need not refer only to constitutional rights in the Bill of Rights. As we have indicated above, the Constitution guarantees (in section 41) that all spheres of government (which would include parliament) must "provide effective, transparent, accountable and coherent government ..." That places an obligation on Parliament and provides those governed by Parliament with a right to insist that it complies with the constitutional guarantee.

One difficulty with these arguments is that the Promotion of Access to Information Act expressly states that it does not apply to records "of an individual member of Parliament or of a provincial legislature in that capacity". ${ }^{55}$ That would suggest that, at least as far as the legislature is concerned, the right of access to information (to which the Promotion of Access to Information Act seeks to give effect ${ }^{56}$ ) does not include the right to access information relating to MPs. However, the contents of the Promotion of Access to Information Act would not necessarily preclude relying on the right of access to information to support a broader interpretation of the PDA. In addition, it is highly unlikely that the "records" relating to MPs that are excluded from the Promotion of Access of Information Act could be taken to include information relating to misconduct by MPs.

It is also noteworthy that, while records relating to MPs are excluded from the Promotion of Access to Information Act there is no corresponding exclusion of disclosures relating to their activities in the PDA. That could be taken as an indication that the legislature intended that disclosures relating to misconduct perpetrated by MPs ought to be protected by the PDA.

As a general observation we would suggest that the PDA must be read as part of a collection of legislation and state institutions (such as the Public Protector and the Auditor-General) which promote openness and accountability. ${ }^{57}$ That further entrenches the notion that those values are to be promoted and extended where appropriate rather than limited.

\section{The right to dignity}

It is trite that the right to dignity is a foundational value in our constitution. ${ }^{58}$ We would suggest that there is a violation of an individual's dignity where that person is punished and humiliated for having had the courage to come forward with important information relating to the misconduct of those in positions of power. Being a whistleblower is an unattractive prospect at the best of times given that it exposes the whistleblower to potential disciplinary action or victimization. It potentially jeopardizes their lives, reputations or

$55 \mathrm{~S} 12$.

56 S 32(2) of the Constitution provides that "National legislation must be enacted to give effect to this right, and may provide for reasonable measures to alleviate the administrative and financial burden on the state".

57 The heading to Chapter 9 of the Constitution refers to the Chapter 9 institutions as "State institutions supporting constitutional democracy".

58 See ss 1(a), 7(1) and 10 of the Constitution; $S \vee$ Makwanyane 19953 SA 391 (CC) 507508; President of the Republic of South Africa v Hugo 19974 SA 1 (CC) 22-23; Ferreira $v$ Levin NO 19961 SA 984 (CC); Dawood v Minister of Home Affairs; Shalabi v Minister of Home Affairs; Thomas v Minister of Home Affairs 20003 SA 936 (CC) 961-962. 
prospects of advancement in the organization after having been branded disloyal by management or their colleagues. ${ }^{59}$ And all this for doing the right thing in revealing improprieties to the benefit of the affected organisation or society in general.

The relevant sentiments are captured in the following dictum from Minister of Justice and Constitutional Development $v$ Tshishonga ${ }^{60}$

"In particular, the respondent suffered the indignity of unfortunate, intemperate attacks of an ad hominem nature made by the Minister of Justice on national television. The gravity of this grossly unfair and irresponsible conduct on the part of the minister was compounded by the role played by the respondent in seeking to promote integrity in government. Respondent further suffered the indignity of losing his employment. All of this occurred because he acted as a 'whistleblower' in terms of the very legislation introduced by first appellant's department, which was designed to protect such people. The Department of Justice is obligated to show the greatest respect for the PDA for, as the promoter of the legislation, it should know the cardinal importance of this Act in promoting the constitutional values of accountability and transparency in the public administration of this country."

If allowing whistleblowers to be prejudiced for their actions is an affront to their dignity it is significant that they have no other effective remedy to protect their dignity than the PDA. The Act acknowledges that in its preamble where it states that:

"neither the South African common law nor statutory law makes provision for mechanisms or procedures in terms of which employees may, without fear of reprisals, disclose information relating to suspected or alleged criminal or other irregular conduct by their employers, whether in the private or the public sector".

The courts should therefore be ready, where possible, to extend the remedies in the PDA to protect one of the central rights in the Constitution.

What we have sought to illustrate above is that the PDA gives effect to and protects a number of fundamental rights. Subsection 39(2) of the Constitution requires courts when interpreting any legislation to "promote the spirit, purport and objects of the Bill of Rights". Courts are instructed to determine whether a statute can be interpreted in a manner that gives effect to constitutional rights. As O'Regan J put it:

"[i]f [the Act] is capable of a broader interpretation that does not limit fundamental rights, that interpretation should be preferred. This is not to say that where the legislature intends legislation to limit rights, and where that legislation does so clearly but justifiably, such an interpretation may not be preferred in order to give effect to the clear intention of the democratic will of parliament. If that were to be done, however, we would have to be persuaded by careful and thorough argument that such an interpretation was indeed the proper interpretation and that any limitation caused was justifiable as contemplated by $\mathrm{s} 36$ of the Constitution".

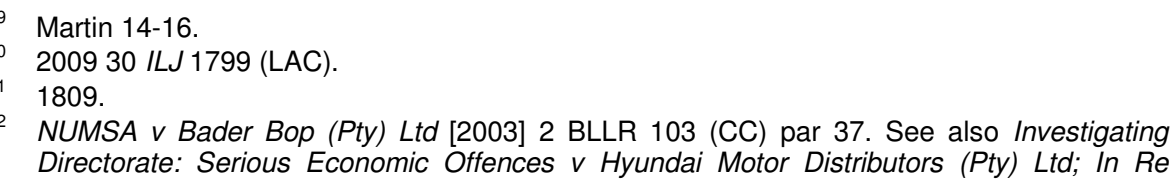


It is far from clear that the definition of "employer" in the PDA excludes MPs. There is nothing in the text to suggest that it does. On the contrary, as we have suggested above taking account of the plain meaning of the words in the definition, MPs could be regarded as employers for the purposes of the PDA. They act on behalf of Parliament in carrying out various administrative functions relevant to the running of Parliament and would thus seem to fall squarely within the definition. To the extent that there is any ambiguity in the definition it should be resolved in favour of including MPs within its ambit. That is what a proper purposive interpretation of the definition requires.

\section{(iii) International law}

If the stated objects of the PDA, the constitutional values of accountability and transparency and the rights in the Bill of Rights were not considered sufficient, the LAC could have been persuaded to give the definition of "employer" a broader interpretation with reference to international law. Section 233 of the Constitution provides that

"[w]hen interpreting any legislation, every court must prefer any reasonable interpretation of the legislation that is consistent with international law over any alternative interpretation that is inconsistent with international law".

We would suggest that in Charlton's case viewing MPs as employers for the purposes of the PDA would have been a reasonable interpretation that was consistent with international law. The LAC made no mention of the relevant international instruments or section 233 of the Constitution. Those were serious omissions.

The United Nations Convention Against Corruption, which has been signed and ratified by South Africa, requires parties to

"develop and implement or maintain effective, coordinated anticorruption policies that promote the participation of society and reflect the principles of the rule of law, proper management of public affairs and public property, integrity, transparency and accountability".

In addition, parties

"shall also consider, in accordance with the fundamental principles of its domestic law, establishing measures and systems to facilitate the reporting by public officials of acts of corruption to appropriate authorities, when such acts come to their notice in the performance of their functions.

And each party

"shall consider incorporating into its domestic legal system appropriate measures to provide protection against any unjustified treatment for any person who reports in good faith and on reasonable grounds to the competent

Hyundai Motor Distributors (Pty) Ltd v Smit NO 20011 SA 545 (CC) 558 et seq; and South African Police Service v Public Servants Association 2007 3 SA 521 (CC) 529.

63 Article 5.1

64 Article 8.4 
authorities any facts concerning offences established in accordance with [the] Convention".

In 2010 the Council of Europe adopted a resolution relating to the protection of whistleblowers. ${ }^{66}$ It recognized the importance of whistleblowers in the public and private sectors and set out a framework for member states drafting whistleblower protection legislation.

The Council of Europe also adopted Criminal Law and Civil Law Conventions on Corruption. ${ }^{67}$ Both of them required parties to adopt measures to provide appropriate protection to those who report criminal offences or (in the civil context) "have reasonable grounds to suspect corruption and who report in good faith their suspicion to responsible persons or authorities". 68

The Organization of American States adopted the Inter-American Convention Against Corruption ${ }^{69}$ which requires parties to create, maintain and strengthen

"Systems for protecting public servants and private citizens who, in good faith, report acts of corruption, including protection of their identities, in accordance with their ${ }_{70}$ Constitutions and the basic principles of their domestic legal systems."

The African Union adopted a Convention on Preventing and Combating Corruption. $^{71}$ In article 3 of the Convention the parties commit themselves to the following principles:

"1. Respect for democratic principles and institutions, popular participation, the rule of law and good governance.

2. Respect for human and peoples' rights in accordance with the African Charter on Human and Peoples' Rights and other relevant human rights instruments.

3. Transparency and accountability in the management of public affairs."

And in Article 5 parties commit themselves to adopt "measures that ensure that citizens report instances of corruption without fear of consequent reprisals".

In 2001 the Southern African Development Community (SADC) adopted a Protocol Against Corruption which South Africa has signed. Parties to the Protocol (in article 4) undertake to adopt measures which will create, maintain and strengthen

"(d) mechanisms to promote access to information to facilitate eradication and elimination of opportunities for corruption [and]

(e) systems for protecting individuals who, in good faith, report acts of corruption."

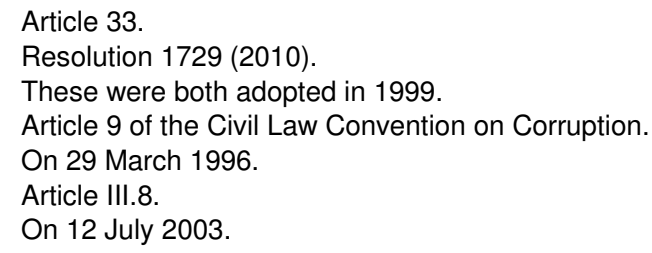


To the extent that these instruments constitute international law they show a clear desire to protect those, whether in the public or private sectors, who disclose information such as that which Charlton reported. The international instruments therefore make an interpretation of the PDA which allows information relating to the misconduct of MPs to be disclosed, one which is consistent with international law. We would suggest that such an interpretation would go some way to furthering South Africa's obligations as a signatory to certain of the instruments cited above. ${ }^{72}$

\section{RELIANCE ON SECTION 5(1)(c)(v) OF THE LRA}

One of Charlton's claims in the Labour Court was that his dismissal was automatically unfair because it was contrary to section 5 of the LRA. Section 187(1) of the LRA makes it automatically unfair to dismiss an employee where "the employer in dismissing the employee acts contrary to section 5". Essentially, section 5 contains protections against victimization for being as member of a trade union or workplace forum or participating in its activities. Significantly for present purposes section 5(c)(v) prohibits anyone from prejudicing an employee because of past, present or anticipated disclosure of information that the employee is lawfully entitled or required to give to another person. That prohibition would seem to cover disclosures relating to misconduct by employers.

Section 5 provides detailed protections of employees' rights to freedom of association. It might thus be suggested that it would only apply to protect employees who disclose information that is connected to the activities of trade unions in the workplace. However, the section clearly also extends beyond freedom of association. That is clear from section 5(1) which provides that "[n]o person may discriminate against an employee for exercising any right conferred by this Act". Subsection 5(4) which prohibits contractual provisions which contradict anything contained in section 5 has been applied outside of the context of freedom of association. ${ }^{73}$ In any event, there seems to be no need to read section 5 narrowly.

It would thus protect any employee who disclosed any information that he was lawfully entitled or required to disclose whether or not that related to an employer's misconduct. There are few instruments that oblige employees to disclose information. One of those is section 34 of the Prevention and Combating of Corrupt Activities Act. That section requires people in positions of authority to disclose information relating to specified suspected offences. Persons in positions of authority are defined in a list and include very senior management in the various institutions mentioned. Section 34 would therefore not oblige the average employee to disclose the specified information. That begs the question when a disclosure would be lawful and thus protected by section 5 . In our view, in the context of disclosures relating to employer misconduct, an employee's disclosure would be lawful if it fell within the bounds of the freedom of expression. That would involve the kind

\footnotetext{
72 That the legislature is desirous of doing so is very evident from the preamble of the Prevention and Combating of Corrupt Activities Act 12 of 2004

73 See, eg, Mahlamu v CCMA [2011] 4 BLLR 381 (LC).
} 
of balancing exercise engaged in by the Canadian courts, an exercise which we have suggested has been adopted by the PDA.

We would suggest that while section 5 is broad enough to cover the disclosure of information relating to employer misconduct, when a court is required to determine whether such disclosure is lawful it must be guided by the provisions of the PDA. That is because the PDA was introduced to deal specifically with when employees may legitimately disclose information relating to employer misconduct. In addition, courts ought to be cautious about protecting employees who make disclosures relating to employer misconduct via section 5 when there is legislation to deal with such situations. The point is that the development of two streams of jurisprudence relating to the same issue is undesirable. The upshot of this is that Charlton's reliance on section 5 was misplaced in the sense that the question of whether he could lawfully disclose the relevant information would in any event have to be determined with reference to the provisions of the PDA. If the court found that MPs were not employers for the purposes of the PDA it would be compelled to find that his disclosure was not covered by the PDA and was thus unlawful for the purposes of section 5.

\section{CONCLUSION}

This paper has sought to examine the decision of the LAC in Charlton critically. The decision is crucially important given that it relates to the extent to which employees in Parliament can disclose information concerning the misconduct of MPs. That in turn raises issues around accountable and transparent government. We have suggested that the LAC's decision subverts those fundamental objectives. There was every reason for the court to find that the PDA covers disclosures relating to the misconduct of MPs (and we have dealt with them in detail above), yet it failed to do so. We have suggested that a proper interpretation of the PDA, having due regard to the objectives of that Act, the essential principles contained in the Constitution and, more particularly the Bill of Rights as well as international law compel one to the conclusion that the PDA can and should be interpreted as applying to disclosures concerning the misconduct of MPs.

The Constitutional Court has repeatedly emphasized that the LAC is a specialized court which was "established by parliament specifically to administer the LRA. [It is] charged with the responsibility for overseeing the ongoing interpretation and application of the LRA and development of labour relations policy and precedent" ${ }^{74}$ In its decision in Charlton, for the reasons we have given above, the LAC failed to demonstrate its specialist status nor did it provide adequate guidance in its role as the overseer of the development of labour-relations policy and precedent.

74 See National Education Health \& Allied Workers Union v University of Cape Town (supra) 110; Dudley v City of Cape Town 200425 ILJ 991 (CC) 994; and Chirwa v Transnet Ltd 200829 ILJ 73 (CC) 90. 